\title{
The System of the State Village Government of the Kazan Governorate in the Early 18th - the First Third of the 19th Centuries
}

\author{
Ramil R. Khayrutdinov ${ }^{1}$ \\ ${ }^{1}$ Kazan (Volga Region) Federal University, Kazan, Russia \\ Correspondence: Ramil R. Khayrutdinov, Kazan (Volga Region) Federal University, 420008, Kazan, \\ Kremlyovskaya Street, 18, Russia. E-mail: ramilh64@mail.ru
}

Received: June 2, 2015 Accepted: June 15, 2015 Online Published: June 29, 2015

doi:10.5539/jsd.v8n5p1 URL: http://dx.doi.org/10.5539/jsd.v8n5p1

\begin{abstract}
The importance of the research is determined by the essential character and necessity of studying the system of the local government of the state village of the Kazan Governorate for a more complete realizing of the political institutions of autocratic Russia. The article is aimed at the study of the state and functioning of the local government system of the Kazan Governorate state village at the turn of the 18th and 19th centuries. The leading method of the research is a complex approach based on the study of different kinds of sources. The research included considering social, economic and legal status of the state peasants in the structure of the rural population paying duty in the Kazan Governorate. The course of formation and the ways of evolution of this class are shown; the problems of land availability and the size of the paid duty are regarded. The structure, functions and scope of authority of the local state institutions and peasant self-government are studied, the professional and ethnic composition of the local administration is investigated, the role of senatorial inspections as an institute of the state control is shown. The effectiveness of the local government and court is analyzed, the problem of peasants' attitude to the authorities is considered; the protest of the state peasants against the feudal and administrative oppression was an essential part of this problem. The materials of the paper may be used in the preparation of the summarizing monographs on the agricultural history of the Middle Volga Region (Central Volga Region), in the teaching practice of universities in delivering lectures and practical classes, in creating special courses on the Tatarstan peasantry history and history of state institutions.
\end{abstract}

Keywords: Kazan Governorate, local authorities, state peasants

\section{Introduction}

The problems of studying the political institutions of autocratic Russia are among the important aims of the modern historical studies. Therefore, the local authorities, including the bodies of state peasantry government, are of great interest. The "state feudalism" policy in relation to the state peasantry was realized directly through the local governing bodies and court (Eroshkin, 1981). The study of the structure, organization and composition of the local administrative apparatus, mechanism of state institutions functioning, forms and methods of peasants management is an essential part of the investigation of the problem of the class essence of the Russian autocracy and its domestic policy of late feudalism (Zayonchkovsky, 1978).

In the context of the multiethnic character of the Middle Volga Region, the analysis of the state and activity of the administrative, operational and financial, police, and judicial bodies of Kazan Governorate is of special importance (Goncharenko, 1984).

Firstly, Kazan Governorate was a typical agricultural, agrarian region with a historically developed predominance of the state peasantry. In the activity of the local authorities and court, the problems of the state village were in the foreground. All this gives the opportunity to identify priorities in the agricultural policy of the autocracy in relation to the state peasants at the local level, to show the ways and methods of its realization in the concrete region, as part of the major and principal administrative subdivision of the Russian Empire - the governorate.

Secondly, Kazan Governorate, the state peasants, the representatives of the indigenous ethnic groups of the region (the Tatars, Chuvash, Mari, Mordva, Udmurt) made up the absolute majority of the population in the investigated period. The study of this problem using the example of Kazan Governorate gives the opportunity to identify both the common patterns and concrete historical peculiarities of the national policy in tsarist Russia. 


\section{Methodological Framework}

\subsection{Research Objectives}

It was necessary to achieve the following objectives as part of the study:

1. To identify the social, economic and legal status of the state peasants in the structure of the rural population paying duty in Kazan Governorate; to show the course of formation and the ways of evolution of this class; to consider the problems of land availability and the size of the paid duty.

2. To study the structure, functions and scope of authority of the local state institutions, peasant self-government; to investigate the professional and ethnic composition of the local administration; to show the role of senatorial inspections as an institute of the state control.

3. To analyze the effectiveness of the local government and court, to consider the problem of the peasants' attitude of to the authorities; the protest of the state peasants against the feudal and administrative oppression was an essential part of this problem.

\subsection{Theoretical and Methodological Basis of the Research}

The complex approach based on the study of different kinds of sources became the methodological basis of the research. Furthermore, the author applied the method of the source analysis for finding and selecting sources and criticizing their content; the method of system and typological analysis helping to reconstruct the full picture of a given event or phenomenon.

\subsection{Source Basis of the Research}

The documents of the late 18th - the first third of the 19th centuries, the bulk of which are the archival materials of the record keeping character related to the functioning of the central and local authorities and court, made the base of the research.

Moreover, the published documentary materials - various statistical information of the central local institutions, and published memoirs of the eyewitnesses of the events related to the history of the region - are the definite part of the source basis of the research.

Some information on the theme of the study was taken from the local periodical press - the newspapers "Kazanskiye Izvestiya" ("The Kazan News") (1811-1820), "Kazanskiy Vestnik" ("The Kazan Messenger" (1821 - 1833), Supplements of the "Kazanskiy Vestnik" (I821 - 1841), "Kazanskiye Gubernskiye Vedomosti” (“The Kazan Governorate News") (1838 - 1917).

\section{Results}

\subsection{The Subject of State Operation}

The legal implementation of the Russian state peasants' class was begun by the reforms of Peter the Great's government. The inclusion of the Tatars and the yasak peasants of the Middle Volga Region (peasants who paid tribute in furs) in the first quarter of the 18th century into the number of state peasants became part of the autocratic Russia's policy aimed at the consolidation of feudal relations in the country, and it legally fixed the serfdom of the region's peasants, which was the dependence on the supreme land owner - the state.

The Russian legislation of the turn of the 18th and 19th centuries defined the social and legal status of the state peasants as formally individually free keepers of the state land and payers of the feudal rent. The dynamics of the government's legislative activity testifies the attention of the state to this peasant class in the studied period (Vyskochkov, 1981).

At the end of the 18th - the first third of the 19th centuries, the formation of the state peasants' class is finished in Kazan Governorate, as well as all over Russia. Forming one social unit, at the same time, the class was divided into numerous groups of peasants, which were different in their history, ethnic background, peculiarities of development, and, finally, in their number. The process of the integration of the former yasak peasants; the service class Tatars and Chuvash; the Morzalar and their servants; smallholders; economic, vacant, designated and session peasants; the state "Little Russians", the Cherkass and other groups into the number of state peasants is observed. During the first third of the 19th century, the free agriculturalists, astringers, yamschiks (coachmen), former agricultural and resigned soldiers got the status of state peasants (Druzhinin, 1946).

During the studied period, state peasants made up over $75 \%$ of the rural population paying duty in the governorate. In 1797-1837 their number rose from 310 up to 445 thousand people of the census record, significantly surpassing the peasants of other classes in the rate of growth. 
The predominance of the communal and service class ownership of land of different social groups of state peasants $-54 \%$ of all the land - was the characteristic feature of the social structure of the governorate land ownership. The ordnance survey could not solve a serious problem of the disputed and alternate ownership of the state peasants and other land holders. Over 403 thousand dessiatins (1,088, 906 acres) of land were shared by the state peasants and landowners.

During the studied period the land resources of the state peasants increased by 5.8 , however, the sizes of land decreased from 13.5 to 7.6 dessiatins for one person of the census record. The inhomogeneity of the land use becomes more intensified in the studies of the ploughed land size of different social groups of state peasants.

The data of the arable production of Kazan Governorate testify the definite positive tendencies in the development of the peasant agriculture. Despite the disadvantageous economic conditions of the beginning of the 19th century, the average bulk yield of the cereal crops in the studied period increased from 230 tonnes to 2,982 tonnes, the average yield indices showed an increase from 2.2 to 2.9 (the ratio of the amount of grain to the number of seeds).

The basis of the system of duties in pre-reform Russia was in the two mutually defining elements - state taxes, including the capitation and rent, and the state duties - monetary and "natural" (obligatory ones).

During the first third of the 19th century, the money relationship changed the structure of obligatory duties. Peasants got an opportunity to change their duties for money contribution in some cases, or to do contracted works (Neupokoyev, 1987).

The yield of the peasant farms depended on many factors: the soil capacity and the amount of ploughed land, weather crop yield, availability of a sufficient number of cattle, the level of agricultural engineering development, practising crafts, etc. During the studied period the intensification of the social differentiation of the state village is observed. According to the level of yield, the peasant farms of the region were divided into 4 groups with the income of 35-60 rubles earned by seasonal peasants and 300-400 rubles earned by affluent peasants. The system of the grain trade, depending on the prices set by wholesalers, which existed in the first third of the 19th century, dramatically reduced the opportunity of sales of agricultural products for peasants. The years of 1828 and 1929 became financially crucial for peasants, when the prices for grain decreased to the lowest level.

High deficiencies of the peasant farms became the consequence of the increase of taxes, duties, fees taken from state peasants, intensifying land scarcity, lack of stability of the economic conditions in the first third of the 19th century. The abuse and arbitrary behaviour of the staff and civil servants of the governing bodies and court played an essential part in this process.

\subsection{The Bodies of Government and Their Functions}

In the studied period, the system of local government did not involve a special institution which would have accumulated the functions of control and guardianship in its work. However, the problem of peasantry was an integral part of the activity of the governor, the governorate's government, the majority of public offices, and, mainly, in the practice of the economic department of the treasury chamber, state and district courts. The disregard for the specifics of the multiethnic region caused the decrease of the effectiveness of government bodies' work, which was intensified by the constant lack of staff in the institutions and lack of highly professional civil servants (Yeroshkin, 1985).

During the 20s of the 19th century there was lack of applicants for the positions at noble elections.

The studied period is marked by a high level of "head officers" turnover - for 40 years 15 people were appointed military and civil governors.

The governorate personnel did not presuppose any institutions meant for the training of the civil servants, recruitment for the state machine of governing the representatives of non-Russian peoples of the Middle Volga Region. The employment of the Tatars, Chuvash, etc. in the system of the state village government was significantly prevented by the birth status and educational background even for the specific kind of work, for example, as interpreters and translators. As a rule, the very few coming from privileged classes could enter the staff of civil servants.

At the turn of the 18th and 19th centuries, a new system of peasant self-government was being formed in Russia by forming the volost organization, which was an intermediate link between the traditional rural "world" and peasant community (Zaitsev, 1912). By 1837 there were 867 rural communities in the volosts of Kazan Governorates.

During the studied period the structure and list of the rural and volost peasant authorities are legislatively registered, the authority of civil servants are worked out and concretized. The structure of the region's state peasants volost government included the administrative units, performing specific functions, - the volost 
government for peasants taking part in the preparation of the ship timber for building the Russian fleet. The organization of governing the agricultural soldiers in Kazan Governorate before the 30s of the 19th century went without the volost administration.

The peculiarities of the region connected with the predominance of the non-Russian peasantry influenced the formation of the election system of the peasant self-government authorities. The consolidation of the affluent peasants' rights to influence the decisions of the volost administration through their appointees was the result of the new election system. The vast majority of the state peasants were barred from forming the peasant government authorities and controlling their activity.

One of the forms of special control of the local government and court system was the introduction of the senatorial inspections at the turn of the 18th and 19th centuries. The legislative registration of the aims and functions of the inspections, designation of the inspectors' competence took place during the reign period of Paul I, who needed to know the real status of the state government system in the country and to control the position of all the units of the local self-government after the introduction of the governorate reform in 1796 (Blinov, 1905). In the senatorial instructions of $1799,1805,1819$, and 1820 much attention was given to the place of state peasants and their relationship with the local government institutions.

The basic cause for appointing an inspection company was a necessity to investigate the matters of abuse described in complaints and requests. The senatorial inspections were different in duration and scope, as well as in the number of duties imposed on the senators.

In Kazan Governorate, most of inspections - four out of five - were appointed by the Senate during the first decade of the 19th century (Korsakova, 1908; Puparev, 1856).

Such frequency of inspections of the local government authorities indicated a persistently high level of civil servants' official malfeasances. The materials of inspections contain the characteristic of the local administrative apparatus, and the analysis of work was made not only on the base of the reports of the local administration subdivisions, but also taking into account the selective inspection of the governorate and district institutions, volost and rural authorities.

As a rule, the basic result of every inspection was the replacement of the delinquent civil servants. At the same time, the senatorial inspections could not improve the effectiveness of the local administrative apparatus, because they were capable only of stating the general tendencies, typical of the government system of autocratic Russia in general.

\subsection{The Crisis of Administration}

The contradictions of the economic and social framework of Russia in the late 18th - the first third of the 19th centuries distinctly affected the functioning of the local administration. The necessity to reform the state peasants' local government was caused by the changing social and economic conditions, and the demands of the increasingly complicated economy of state farms.

The government bodies and courts turned out to be incapable of performing effectively the functions and duties imposed on them. The activities of the Kazan governorate institutions, though defined by the specific character of the ethnic and social composition of the region's peasants, was characterized, during the studied period, by the features typical of the administrative apparatus of autocracy: bureaucracy, fiscal and police orientation, incompetence of civil servants, and high level of official malfeasance.

State peasants could not count on the judges' neutrality and impartial solutions of cases in the district courts and chambers of civil and criminal courts. More than $50 \%$ of judgments in the district courts of the first quarter of the 19 th century turned out to be completely or partially wrong. The mean time of the lawsuit in the district courts was 3 years, and in courts of all levels - 16 years and 4 months (Zalessky, 1905).

The rural and volost government of the governorate faced heavy pressure from the whole structure of local state institutions. This pressure was in the intention to subdue the peasant "world" for the fiscal aims of governing, which were collecting duties and deficiencies, heavy regulations of the life of rural community, sometimes by means of destroying the traditional way of life of peasants belonging to different ethnic and social groups. The obvious duty-and-police orientation of functions of the local government also determined the activities of the lower echelon, which was, in practice, the grassroots unit of the executive bodies.

The rural volost record-keeping and the financial statement of the volost government of Kazan Governorate in the first third of the 19th century were in the state of neglect. The breach of the law was caused not only by the greed of the rural chiefs and pressure from civil servants and the staff of the governorate and district institutions, but also by 
the insistence of the state peasants. They were the initiators of bribe giving, hoping to facilitate their duties in this way, mainly, during the period of recruitment.

The state peasants of Kazan Governorate carried the heaviest burden of arbitrary treatment, abuse, bureaucracy, and ethic corruption of the local administration. That particular fact alongside the deterioration of the economic conditions caused the protests of the district's peasantry, which were expressed in different forms: from complaints and requests to mass unrests. The peasants' fight against the oppression of the administrative and judicial bodies, civil servants and the staff of the local administrative apparatus was closely intertwined with the opposition to ruinous taxes, duties, national oppression, and was objectively aimed against the existing system of state feudalism" of Russia before the reforms (Sofronov, 1952).

Making complaints and requests, including those in the Tatar language, addressed to the local and central governmental bodies was the most widespread form of protest among state peasants of Kazan Governorate, as well as of the whole peasantry of Russia during the period under research. These documents, coming from peasantry, distinctly reflect the system of exploitation of state peasants.

The forms of protest were various - illegal cutting of timber; refusal to fulfill duties, pay deficiencies; escapes and other forms of opposition. The peasants' fight against the administrative oppression was targeted at the consolidation of the real peasant self-government. The peasants protested against the interference of local administration in the matters of the rural community, against the candidates for the posts of volost chiefs and clerks who were put forward by the members of the district police. From 1822 till 1833, 24 people were banished from Kazan Governorate to Siberia for "the insubordination to superiors and opposition to the legitimate authorities" (Khayrutdinov, 2002).

Non-Russian state peasants were imposed to national oppression, and prejudice of religious feelings alongside the administrative oppression. The peasants' campaign against the forcible Russification and Christianization, violation of national dignity was expressed in such specific forms of protest as renunciation of Orthodox Christianity and adoption of Paganism and Islam. According to the official data of the 1829, 249501 (65\%) people out of 383920 proselyted Christians were ready to return into their original faith in Kazan Governorate. In the 30s of the 19th century, the government tightened the fight against such peasants, passing from admonitions to forceful removal.

\section{Discussions}

In the 60-70s of the 19th century, a range of works covering the activity of the governorate authorities were published. In the works by I.E. Andreevsky, A.V. Lokhvitsky, E.N. Anuchin special attention was paid to the history of formation of the governorate administrative institutions, the role of the governor in the general administration of the governorate is shown (Andreevsky, 1864; Anuchin, 1872; Lokhvitsky, 1864). The research by I.Blinov, published in 1905 considers the same issue (Blinov, 1905). The problems of local administration are covered in separate chapters of summarizing works of the late 19th - early 20th centuries by such brilliant lawyers of the pre-October period A.D. Gradovsky, V.V. Ivanovsky N.M. Korkunov N.I. Lazarevsky et al. (Gradovsky, 1904; Korkunov, 1913; Ivanovsky, 1908; Lazarevsky, 1908-1910; Syromyatnikov, 1913). The excellent knowledge of legislation let them represent the gradual development of the structure of local government institutions, however, lack of concrete historical, factual material, departure from consideration of social and economic conditions of the legislation realization in relation to peasantry in the research contributed to the distortion of the real state of affairs.

The activity of the local authorities in accordance with to their departmental affiliation is considered in the numerous anniversary departmental publications of the early XX century. Such works as "The history of the Governing Senate for two hundred years", "The history of The Ministry of Internal Affairs" by N. Varadinov, "The historical survey of the activity of the Committee of Ministers" by S.M. Seredonin, "Ministry of Finance. 1802-1902", etc. (Akhun, 1939, 1911; Varadinov, 1853; Seredonin, 1902) are of the greatest interest.

The peculiarity of works by lawyers and historians of law was the analysis of peasantry government bodies according to the linear principle (separately, governorate, district, volost level of command), accompanied by the frequent disregard of vertical communication between them - the real cooperation of different institutions of the state village administration system. A.M. Zablotsky-Desyatovsky (1882), V.I. Semevsky (1885), I. Strakhovsky (1903), A.S. Lappo-Danilevsky (1905), A.L. Kizevetter (1910), S.A. Knyazkov (1911), S.P. Kavelin (1912) were close to the complex coverage of this problem in their works, mainly concerning the government reform of 1837-1841.

The structure and activity of the elected peasant self-government of pre-reform Russia in 1797-1837 is profoundly 
considered in one of the chapters of K.N. Zaitsev's research (1912). The analysis of the activity of central economic governmental bodies of the state village is given in the articles by V.I. Veshnyakov (1901), the activity of the administrative authority - in the work by V.E. Den (1902), economic and financial institutions - in the book by Ya.I. Kozlovsky (1901). The works by E.P. Karnovich (1887), V.A. Evreinov (1888) cover to the problems of recruitment of civil servants for state institutions. Separate subjects of this research were covered in the books and articles by pre-revolutionary Kazan historians and lawyers: K. Fuks (1991), A.G. Puparev (1856), M. Laptev (1861), S.M. Shpilevsky (1877), V.D. Korsakova (1908), N.Ya. Agafonov (1906), N.L. Zagoskin (1893), V.F. Zalessky (1905) et al.

The Soviet historiography of the state village history research is rather extensive (Vyskochkov, 1981). The interest in the state peasants of pre-reform Russia noticeably increased after the publication of the landmark book by N.M. Druzhinin. This monograph suggests a thorough analysis of the social, economic and legal status of state peasants in close relation to the preparation and implementation of the reform initiated by Pavel Kiselyov (Druzhinin, 1946, 1940). Most of the following works of the Soviet historians of the 40-50s in the local aspect cover the problems of the same period (Vyskochkov, 1981). The situation of the state peasants of the district in the 30-60s of the 19th century is studied by the materials of Kazan Governorate by E.I. Chernyshov (1952), M.G. Sofronov (1952), B.G. Plushchevsky (1953), P.V. Ozerov (1940), P.G. Grigoryev (1942). In this background, the work on the study of the status of the state peasants in Russia before the reform of 1837-1841, done by S.I. Khvorostin at the end of the 40s remains almost unnoticed (Khvorostin, 1947). The author of the master's thesis summarized the works of the pre-revolutionary law historians, and carried out thorough interpretation of materials of the legislative acts referring to the structure of the governmental bodies and the sphere of their authority.

A new momentum for the study of the local state institutions is connected with the name of N.P. Eroshkin. In his works, and particularly in his special work written in 1985, N.P. Eroshkin covered the formation of the departmental system of local state apparatus in Russia from the beginning of the 19th century, considered the problem of classifying the local governmental and judicial bodies (Eroshkin, 1981, 1983, 1985). The peasantry administration is shown in the broad background of social and political changes in Russia of the first half of the 19th century and the evolution of the political institutions of autocracy. The works covering the problems of political history of autocratic Russia at the beginning of the 19th century and the fight around the reforms are important for understanding the changes in the peasantry problem from the side of the government and central authorities. Among these are the works by A.V. Predtechensky (1957), S.B. Okun (1974), A.I. Parusov (1963), V.M. Golikov (1983), V.I. Neupokoev (1987), M.M. Safronov (1988), S.V. Mironenko (1989). The issues of the formation of the government apparatus, the structure of officialdom, mainly those of the supreme and governorate administration are considered by P.A. Zaionchkovsky (1978), L.E. Shepelev (1991, 1999).

In the 60-80s the study of peasantry carried out by the historians of the Middle Volga Region (Kashtanov, Litvin, Smykov 1967; Ionenko, Wulfson, Usmanov, 1984) significantly advanced. The essential contribution into the investigation of separate aspects of history of state peasants of the region of the late 18th - the first half of the XIX centuries was made by V.D. Dimitriyev (1986), V.S. Khaziakhmetova (1978), E.P. Pogodin (1984), A.S. Kazimov (1980) et al. The works by S.Kh. Alishev (1990), I.A. Gilyazov (1982), Z.S. Minnullin (1992), N.A. Khalikov (1981), Austrian researcher A. Kappler (1984) study of the social, economic and legal status of the Tatar peasantry.

The most general issues about the local administraion of state peasants are presented in the corresponding chapters of the summarizing monographs on the history of Tatarstan, Chuvashia, and the Mari El Republic. Separate aspects of the theme under study were researched by A.V. Garzavina (1990), L.M. Gavrilova (1988). In the works by L.N. Goncharenko (1984) and I.I. Smykov (1984) the state and functioning of autocratic administrative apparatus of the governorate in the late 19th - early 20th centuries is studied.

The significant breakthrough in the research of state peasants of the Middle Volga Region occured at the turn of the 20th -21 st centuries, when the summarizing publications and monographs by R.R. Khayrutdinov (2002), A.I. Nogmanov (2005), G.N. Kadykova (2006), A.V. Merkushin (2002) et al. were published.

\section{Conclusion}

The researched, carried out in accordance with the targeted aims and objectives, gives the opportunity to formulate the following conclusions.

The state peasants of Kazan Governorate were a large group of the Middle Volga Region peasants, complicated in both ethnic and social composition. During the first third of the 19th century the process of further rapprochement and confluence of different social groups into a joint mass of independent population, in legal 
and economic aspects, took place within the class of state peasants in Russia. The state peasants, who were formally individually free and possessed a range of rights and benefits, recognized by the legislation of Russia of the early 19th century, were in enslaving feudal dependence on the supreme land owner - the state. The state represented by the central and local governmental bodies firmly regulated the civil rights of peasants and their economic activity.

The predominance of state peasants' communal ownership of land was a characteristic feature of Kazan governorate in the studied period. The ordnance survey performed at the turn of the 18th and 19th centuries could not solve a serious problem of the disputed and alternate ownership of the state peasants and other land holders. The increase of the land reserves was accompanied by the decrease of the sizes of land for one person. The measures taken by the government and governorate authorities concerning the decrease of land scarcity in the state village of the region by the way of giving land from the state-owned fund, removal of some peasant families, and giving a permission to take possession of land turned to be inefficient in the background of the social differentiation of the state village.

The economic status of the region's state peasants significantly deteriorated during the period under study. It appeared to be the direct consequence of the unreasonable increase of taxes and duties, enhancing land scarcity, lack of stability in economic conditions of the first third of the 19th century. Lack of considered agricultural policy of the local administrative apparatus, indifferent attitude to the peasants' demands, abuse and despotism of civil servants and administrative staff played their role in this process.

During this period, the structure of the local authorities of Kazan Governorate, as well as that of Russia in general, did not include a special institution responsible for governing the state village. The system of local administration did not have a body combining the functions of control and real guardianship in its activity. The problem of peasants was very important in the functioning of the majority of the administrative, police, judicial, operational and financial institutions, especially the treasury chamber, state and district courts. Lack of economic bodies of the government at the district level enhanced the detachment of the authorities from the real life of peasants, predetermined the paper-based, bureaucratic character of relationship between different units of local administration, on the one part, and the state peasantry - on the other.

The disregard for the specifics of the multiethnic region caused the decrease of the effectiveness of local administrative and judicial bodies' work. The low level of professional qualification of civil servants, and constant lack of staff in the institutions, constant lack of highly professional civil servants characterized the whole structure of the governorate government. The birth status, educational background and paucity of privileged classes significantly impeded their employment with the governorate and district local government bodies.

At the turn of the 18th and 19th centuries a new system of local government for state peasants is formed in Russia. An intermediate link - the volost organization - appears between the traditional rural world and local administrative bodies. During this period the structure and list of the volost and rural authorities are legislatively registered, the functions of peasant civil servants are defined. These processes had special features in Kazan Governorate. The peculiarities of the district connected with the predominance of non-Russian peasantry influenced the introduction of a more rigid system of election of the peasant self-government authorities, interference of the district police in the affairs of peasant community, and the attitude to the elective civil servants.

The senatorial inspections of Kazan Governorate of the early 19th century fixed a high level of official malfeasance of the administrative apparatus, and low effectiveness of governmental bodies' activity. The data of inspections represent the situation of violence and despotism from the side of the local administration to the state peasants, national oppression, and prejudice of religious feelings. The dismissal and committal for trial of approximately one thousand civil servants of governmental institutions and court of Kazan Governorate performed by senators became one of the most significant acts of this kind in pre-reform Russia. The inspections could not improve the effectiveness of the local administrative apparatus, because they were capable only of stating the general tendencies, typical of the government system of autocratic Russia in general.

The activities of the governorate and district level institutions, was characterized, during the studied period, by the features typical of the administrative apparatus of Tsarist autocracy: bureaucracy, incompetence of civil servants, and high level of official malfeasance. The volost and rural government units of Kazan Governorate faced heavy pressure from the side of governorate and district administration in the first third of the 19th century. This pressure was in the intention to subdue the peasant self-government for the fiscal aims of governing, which included collecting duties and deficiencies. The rural elective bodies and the volost administration were, in 
practice, the grassroots unit of the executive bodies, performing the fiscal and police functions.

The abuse of peasantry government civil servants led to the peasants' disapproval of all the measures taken by the local administration, even the positive ones. The actions of the state peasants of Kazan Governorate, as well as of the whole peasantry of Russia in general, were objectively aimed at the weakening of administrative and feudal oppression. Different in the directions of fight, in the forms of manifestation, the peasants' movement always included the protest against the anti-popular activity of the administrative, judicial, police and economic apparatus of government. The main means of peasants' protest was making complaints and requests, but as early as in the 20s of the 19th century the active opposition of peasants of different ethnicities was intensified in Kazan Governorate.

The general contradictions of the economic and social framework of Russia of the late 18th - the first third of the 19th centuries (the period of the feudal system crisis) influenced the functioning of the state village local government system of Kazan Governorate. The government bodies turned to be incapable of performing the functions and duties imposed on them.

The long-felt needs of reforming the local government of state peasants resulted from the changing social and economic conditions and demands of state farms.

At the same time, positive processes are observed in the development of the peasant economy of the region. Despite the oppression, the state village preserved its sustainable economic strength. This is proved by the facts of the natural increase of the number of state peasants, the increase of the grain croppage and the average yield of cereal crops, the increase of the number of peasants practicing crafts, trade, etc. During the studied period, the social and economic situation in the state village of Kazan Governorate was defined not as much by the crisis phenomena in the sphere of economics, as by the crisis of administration.

\section{Recommendations}

The practical value of the research is that its findings and conclusions may be used in the preparation of the summarizing monographs on the agricultural history of the Middle Volga Region, in the teaching practice of universities in delivering lectures and practical classes, in creating special courses on the Tatarstan peasantry history, and history of state institutions.

\section{Acknowledgments}

This work was funded by the subsidy allocated to Kazan Federal University for the state assignment in the sphere of scientific activities.

\section{References}

Agafonov, N. Ya. (1906). From the history of Kazan. Kazan.

Akhun, M. (1911). The History of the Governing Senate for two centuries. Saint-Petersburg.

Alishev, S. Kh. (1990). The historical fates of the Middle Volga Region peoples. The 16th-early 19th centuries. Moscow.

Andreevsky, I. E. (1864). About the vicegerent, voivodes and governors. Saint-Petersburg.

Anuchin, E. N. (1872). The Historical survey of the administrative and police institutions in Russia. Saint-Petersburg.

Blinov, I. (1905). Governors. The historical and juridical sketch. Saint-Petersburg.

Chernyshev, E. I. (1952). The social and economic sketches on the history of the Kazan region in the 19th century. (Unpublished master's thesis). Moscow.

Den, V. E. (1902). The population of Russia according to the fifth inspection. Moscow.

Dmitriyev, V. D. (1986). Chuvashia at the times of feudalism (The 16th-early 19th centuries). Cheboksary.

Druzhinin, N. M. (1940). State peasants in the nobility and government projects of 1803-1833. Historical notes, 7 , 149-181.

Druzhinin, N. M. (1946). The state peasants and the reform of P.D. Kiselyev. Moscow - Saint-Petersburg.

Eroshkin, N. P. (1981). The peasant autocracy and its political institutions (The first half of the 19th century). Moscow.

Eroshkin, N. P. (1983). The history of the state institutions of pre-revolutionary Russia. Moscow.

Eroshkin, N. P. (1985). The local state institutions of pre-reform Russia (1800-1980). Moscow. 
Evreinov, V. A. (1888). The civil promotion in rank in Russia. Saint-Petersburg.

Fuks, K. (1991). The Kazan Tatars in the statistic and ethnographic aspects. The brief history of Kazan. Kazan.

Garzavina, A. V. (1990). We will devote the emotions of our soul to the Motherland. (Decembrists and Kazan). Kazan.

Gavrilova, L. M. (1988). The bureaucracy and clergy of Chuvashia in the 19th - early 20th centuries: The problems of history of the 19th-early 20th centuries. Cheboksary.

Gilyazov, I. A. (1982). The Tatar peasantry of the Middle Volga Region in the second half of the 18th century. (Unpublished master's thesis). Moscow.

Golikov, V. M. (1983). The State Council of Russia in the first half of the 19th century. (Unpublished master's thesis). Moscow.

Goncharenko, L. N. (1984). The administrative apparatus of the autocracy in the national areas of the Middle Volga Region. 1878-1904 (By the materials of Kazan Governorate). (Unpublished master's thesis). Kuybushev.

Gradovsky, A. D. (1904). The basics of the Russian constitutional law. The local self-governmental bodies: Collected edition. Saint-Petersburg.

Grigoryev, P. V. (1942). The unrest of the Chuvash peasantry in 1841-1842. Proceedings of Chuvash Research Studies Institute, 1, 3-54.

Ionenko, I. M., Vulfson, G. N. \& Usmanov, M. A. The history of the peoples of the Volga Region and the Urals from the earliest times up to nowadays. Problems and aims of study: Pages of History of the Volga Region and the Urals. Kazan.

Ivanovsky, V. V. (1908). Manual on constitutional law. Kazan.

Kadykova, G. N. The state Mari peasants of the Middle Volga Region in the late 18th - the first half of the 19th centuries. (Unpublished master's thesis). Cheboksary.

Kappeler, A. (1982). Russlands erste Nationalitaten. Das Zarenreich und die Völker der Mittleren Wolqa vom 16. bis 19. Jahrhundert. Köln; Wien.

Karnovich, E. P. (1887). The Russian bureaucracy at the past and present time. Saint-Petersburg.

Kashtanov, S. M., Litvin, A. L., \& Smykov, Yu. I. (1967). The peasantry of the Middle Volga Region in the Russian and Soviet historical literature: the issues of Historiography and Source Studies. Kazan.

Kavelin, S. P. (1912). The historical sketch of the land organization of the state peasants. Proceedings of the boundary engineers society, 2.

Kazimov, A. S. (1980). The peasant economics in Maryland in the first half of the 19th century. Proceedings of Mari Research Studies Institute, 44, 87-113.

Khalikov, N. A. (1981). The agriculture of the Tatars of the Volga Region and the Urals of the 19th - early 20th centuries. The historical and ethnographic research. Moscow.

Khayrutdinov, R. R. (2002). The administration of the state village of Kazan Governorate. The late 18th-the first third of the 19th centuries. Kazan.

Khaziakhmetova, V. S. (1978). The state village of the Kama and Volga Region of the period of the serfdom abolition. (Unpublished master's thesis). Kazan.

Khvorostin, S. I. (1947). The sketches of the state peasant's status before the reform of P.D. Kiselyov. (Unpublished master's thesis). Leningrad.

Kizevetter, A. A. (1910). The local self-government in Russia. Saint-Petersburg.

Knyazkov, S. A. (1911). Graf P.D. Kiselyov and the state peasants' reform. The great reform, 2, 209-233.

Korkunov, N. M. (1913). The Russian constitutional law. Saint-Petersburg.

Korsakova, V. D. (1908). The list of the civil servants in the towns of present Kazan governorate from 1553 to the formation of Kazan Governorate in 1708 г., and that of the governors, vicegerents, governor generals and military governors governing Kazan Governorate from 1708 up to 1908 and including. Kazan.

Kozlovsky, Ya. I. (1901). The Kazan chambers and subordinate authorities in Russia: The history and modern organization in accordance with the brief description of the state administration organization in general. Riga. 
Lappo-Danilevsky, A. S. (1905). The sketch of the formation of the major peasant population classes in Russia. Saint-Petersburg.

Laptev, M. (1861). Materials for the geography and statistics of Russia accumulated by the officers of the General Staff. Kazan Governorate. Saint-Petersburg.

Lazarevsky, N. I. (1908-1910). Lectures on Russian constitutional law. Saint-Petersburg.

Lokhvitsky, A. V. (1864). The Governorate, its zevstvo and government institutions. Saint-Petersburg.

Merkushin, A. V. (2002). The state peasants of Penza Governorate in the late 18th - the first half of the 19th centuries. (Unpublished master's thesis). Saransk.

Mironenko, S. V. (1989). Autocracy and reforms. The political fight in Russia in early 19th century. Moscow.

Neupokoyev, V. I. (1987). The state duties of peasants of European Russia in the late 18th-early 19th centuries. Moscow.

Nogmanov, A. I. (2005). Autocracy and the Tatars. Kazan.

Okun, S. B. (1974). The History of the USSR: (Lectures). Leningrad.

Ozerov, P. V. (1940). The Mari in the Peasants' Revolt of 1842 in the Volga Region. Proceedings of Mari Research Studies Institute, 2, 29-65.

Parusov, A. I. (1963). From the history of the state peasants of Russia of the first quarter of the 19th century. Proceedings of State University of Gorky, 58, 81-112.

Plushchevsky, B. G. (1953). The State peasants of Vyatka Governorate in the first half and in the middle of the 19th century. (Unpublished master's thesis). Izhevsk.

Pogodin E. P. (1984). Land ownership and land tenure in Chuvashia in the first half of the 19th century; the issues of history of agriculture in Chuvashia. Cheboksary.

Predtechensky, A. V. (1957). The sketches of the social and political history of Russia of the first quarter of the 19th century. Moscow.

Puparev, A. G. (1856). The Kazan governors. Sketch. Kazan.

Safronov, M. M. (1988). The problems of the reforms in the government politicy of Russia at the turn of the 18th and 19th centuries. Moscow.

Semevsky, V. I. (1885). The History of the peasants' problem concerning the history of domestic housekeeping of Russia in the 18th and the first half of the 19th centuries. Saint-Petersburg.

Seredonin, S. M. (1902). The historical survey of the activity of the Committee of Ministers. Saint-Petersburg.

Shepelev, L. E. (1991). The titles, uniforms and orders in the Russian Empire. Leningrad.

Shepelev, L. E. (1999). The bureaucratic world of Russia. The 18th-early 19th centuries. Saint-Petersburg.

Shpilevsky, S. M. (1877). The concerns of Emperor Alexander I about Kazan. Kazan.

Smykov, Yu. I., \& Goncharenko, L. N. (1984). The peasantry and administrative apparatus of Kazan Governorate in the last quarter of the XIX century: Research on the history of peasantry of Tatarstan of the pre-October period. Kazan.

Sofronov, M. G. (1952). The state peasants of Kazan Governorate and the reform of P.D. Kiselyov. (Unpublished master's thesis). Kazan.

Strakhovsky, I. V. (1903). The peasants' rights and institutions. Saint-Petersburg.

Syromyatnikov, B. I. (1913). The brief review and sources of literature on the history of the state authority in Russia. Moscow.

Vardanov, N. (1853). The history of the Ministry of Internal Affairs. Saint-Petersburg.

Veshnyakov, V. I. (1901). The study of the state farm. The olden time of Russia, 10, 195-205.

Vyskochkov, L. V. (1981). The problem of state peasants of the pre-reform period in the Soviet historiography: The genesis of capitalism in Russia in the national historiography. Yaroslavl.

Zabolotsky-Desyatovsky, A. P. (1882). Graf P.D. Kiselyev and his time. Saint-Petersburg.

Zagidullin, I. K. (1992). Tatar peasants of Kazan Governorate in the second half of the XIX century (60-90s). (Unpublished master's thesis). Kazan. 
Zagoskin, N. P. (1893). Emperor Paul I in Kazan. The year of 1798. Kazan.

Zaionchkovsky, P. A. (1978). The government apparatus of autocratic Russia in the 19th century. Moscow.

Zaitsev, K. N. (Ed.). (1912). The sketches of the history of the state peasants' self-government. Works of the economical faculty students of Saint-Petersburg Polytechnic University. Saint-Petersburg.

Zalesskiy, V. F. (1905). The civil practices of the Kazan judicial institutions of the first quarter of the 19th century. The Ministry of Justice Journal, 3, 205-243.

Akhun, M. (1939). The sources for the study of the history of the state institutions of tsarist Russia. Archival file, 1(49), 84-88.

\section{Copyrights}

Copyright for this article is retained by the author(s), with first publication rights granted to the journal.

This is an open-access article distributed under the terms and conditions of the Creative Commons Attribution license (http://creativecommons.org/licenses/by/3.0/). 